\title{
Materiality of Mehmet II Smelling A Rose Based on Gentile Bellini's Painting with Cultural Perspective
}

\author{
Gül Koklayan II. Mehmet Tablosunun Gentile Bellini'nin Tablosu Temelinde Kültürel \\ Açıdan Önemi
}

\section{Tuğba Batuhan*}

\begin{abstract}
This paper examines the painting of Mehmet II, which was painted by Sinan Bey/ Şiblizade Ahmed based on the painting by Gentile Bellini. Those works of art show Mehmet the Conqueror in the same perspective by using different materials and styles of painting. Mehmet II is depicted as the Conqueror of Constantinople in this painting and the painting also includes concepts of Ottoman culture. This paper illustrates the ways in which particular Western elements of art commingled with traditional Turkish art imagery to depict the Sultan's power over Constantinople. Both paintings represent different aspects of Mehmet the Conqueror. Both painters convey their own cultural consciousness and impressions in their paintings. Even though, Gentile Bellini and Şiblizade Ahmed made a similar artistic creation, they present different perspectives of Mehmet II within their own cultural framework. In addition, this paper shows how a local artist was inspired by a foreign artist. Furthermore, the two paintings are explained based on the objects and features used. In conclusion, this study shows that both paintings are also arranged within their own long memory and different social, cultural, and historical point of views to materiality.
\end{abstract}

\section{Keywords}

Mehmet the Conqueror, Gentile Bellini, Painting, Culture

\section{Öz}

Bu makale, Sinan Bey veya Şiblizade Ahmed tarafından Gentile Bellini'nin resmine dayanarak yapılan Fatih Sultan Mehmet'in tablosunu ele almaktadır. Bu sanat eserleri Fatih Sultan Mehmet'i, farklı malzeme ve stiller kullanmalarına rağmen aynı açıdan göstermektedir. Fatih Sultan Mehmet Konstantinopolis'in Fatihi olarak resmedilmekle birlikte, bu resimler Osmanlı kültürel kavramlarını da içermektedir. Makalede, belirli Batı sanatı öğelerinin, Sultan’ın Konstantinopolis üzerindeki gücünü tasvir etmek için geleneksel Türk sanat imgeleriyle nasıl bir araya getirildiğini de göstermeye çalışmaktadır. Fatih Sultan Mehmet'in yer aldığı bu iki tabloda, Sultan'ın bir saray ressamı ve bir yabancı ressam tarafından farklı yönleri tasvir edilmektedir. Burada, her iki ressamın da sahip oldukları kültürel bilinci ve izlenimi resimlerine aktardıkları görülmektedir. Gentile Bellini ve Şiblizade Ahmed, benzer sanatsal eserler ortaya çıkarmış olsalar da Fatih Sultan Mehmet’i kendi kültürel çerçeveleri içinde farklı bakış açısıyla sunmaktadırlar. Ek olarak, bu makale yabancı bir sanatçının yerel bir ressama nasıl ilham kaynağı olduğunu da göstermektedir. Ayrıca, iki resim sanatçıların kullanıldıkları nesnelere ve özelliklere dayanarak açıklanmıştır. Sonuç olarak, bu çalışma her iki resmin kendi sahip olduğu uzun süreli bellek ve farklı sosyal, kültürel ve tarihsel bakış açıları içinde düzenlendiğine işaret etmektedir.

\section{Anahtar Kelimeler}

Fatih Sultan Mehmet, Gentile Bellini, Resim, Kültür

* Correspondence to: Tuğba Batuhan (Asst. Prof. Dr), Mardin Artuklu University, Faculty of Arts, Department of Art History, Mardin, Turkey. E-mail: tugbabatuhan@artuklu.edu.tr ORCID: 0000-0003-0045-4304

To cite this article: Batuhan, Tugba. "Materiality of Mehmet II Smelling A Rose Based on Gentile Bellini's Painting with Cultural Perspective." Art-Sanat, 14(2020): 1-16. https://doi.org/10.26650/artsanat.2020.14.0001 


\section{Genisletilmis $\ddot{O}_{z, e t}$}

Osmanlı padişahı Fatih Sultan Mehmet, sanatı seven, sanatçılara değer veren ve destekleyen bir kişiliğe sahipti. Sanata duyduğu ilginin yanı sıra bu alanda kendisini daha fazla geliştirebilmek adına dersler aldı. Aynı zamanda, hümanist entelektüel eğilimlerin de takipçisiydi. Bunların yanı sıra, çok yönlü kişiliği ile mimari tasarım, bronz döküm ve resimde perspektif konularının da takipçisi olduğu ve hayatının son on yıllık döneminde birçok İtalyan ve Yakın Doğu sanatçısı ile ilgili farkındalığının arttığı bilinmektedir. Kendisi özellikle İtalya ve İtalyan sanatçılarına odaklanmıştı. Sadece Fatih Sultan Mehmet değil onun oğlu II. Bayezid, 1502 ve 1506 yıllarında, Leonardo ve Michelangelo gibi usta isimleri İstanbul'a davet etti. Ancak, II. Bayezid'ın daha çok mühendislik alanındaki girișimleri öne çıkmıștır. Osmanlı padișahları içinde sanatla ilgilenen tek isim Fatih Sultan Mehmet değildir fakat 16. yüzyılda İstanbul'a figür sanatçılarının davet edilmediği de anlaşılmaktadır. 1578 tarihlerinde Sokullu Mehmet Paşa'nın sanat alanında girişimlerinin olduğu ve devlet albümü hazırlatmaya çalıştı̆̆ bilinmektedir. Aynı zamanda, 1575 ve 1578 yıllarında Paolo Giovio tarafından Osmanlı sultanlarının tasvirlerinin yer aldığı iki kitap yayınlanmıştır. Osmanlı Devleti'nde Fatih Sultan Mehmet ve Kanuni Sultan Süleyman dışındaki diğer sultanların fiziksel ikonografisi yoktur. Bu nedenle, Fatih Sultan Mehmet portreleri Osmanlı sanat tarihi içinde önemli bir yere sahiptir.

Bu çalışmada Fatih Sultan Mehmet'in iki ressam, Gentile Bellini ve Şiblizade Ahmed, tarafından yapılmış olan portreleri incelenerek eserlerin benzer ve ayrışan yönleri gözler önüne serilmektedir. Aynı zamanda Gentile Bellini’nin tablosu (Fatih Sultan Mehmet Portresi) temelinde Şiblizade Ahmed'in tablosu (Gül Koklayan Fatih Sultan Mehmet Portresi) değerlendirilmektedir. Çalışma, Fatih Sultan Mehmet'le ilgili sadece iki tabloyla sınırlandırılmıştır. Bu sanat eserleri Fatih Sultan Mehmet'i farklı etkilere sahip aynı bakış açısıyla göstermektedir.

Gentile Bellini'nin eserinde Fatih Sultan Mehmet Konstantinopolis'in Fatihi olarak tasvir edilmiş ve Osmanlı kültürel kavramlarıyla beraber ele alınmıștır. Bu tablo, Fatih'in batı Avrupa tarzında resmedilmiş bir görüntüsüdür. Bellini, Fatih'in portresini yapmaya İstanbul'da başlamış ancak Venedik'te tamamlamıştır. Tablonun ne zaman yapıldığı ile ilgili net bir bilgi bulunmamakla birlikte, Bellini'nin hayatına dayanarak tablonun 1480'lerde yapıldığı düşünülmektedir. Gentile Bellini’nin tablosu batı öğeleri ve Türk sanat imgelerini bir araya getirerek Fatih'in Konstantinopolis üstündeki gücünü göstermektedir.

Kaynakların büyük bir çoğunluğu tarafindan Gül Koklayan Fatih Sultan Mehmet tablosu Sinan Bey'e atfedilmektedir. Osmanlı saray ressamları arasında yer alan Sinan Bey, büyük ihtimalle Avrupalı bir ressamdan eğitim almıştı. Osmanlı saray ressamı olarak doğu ve batı kültürlerinin sentezini resimlerde uygulayan sanatçı, sahip olduğu bilgilerini Şiblizade Ahmed gibi öğrencilerine aktarmıştı. Sinan Bey hakkında 
çok fazla bilgi bulunmamasına rağmen Şiblizade Ahmed'in portre çalışmalarında çok başarılı olduğu bilinmektedir. Şiblizade Ahmed'in Avrupa tarzı portre yapımını ikinci kaynaktan, yani hocası Sinan Bey'den öğrendiği göz ardı edilmemelidir. Ancak, Şiblizade Ahmed'in portre yapımında Bellini kadar usta bir sanatçı olduğu da söylenmektedir. Bu açıdan düşünüldüğünde Fatih Sultan Mehmet'in gül koklarken yapılan portresi Şiblizade Ahmed tarafından resmedilmiş olabilir.

Her iki tablo da Fatih Sultan Mehmet'i farklı bakış açılarından temsil etmektedir. Sultanın fiziksel özellikleri hemen hemen iki tabloda da benzerlik göstermektedir. Bununla beraber, Gentile Bellini tablosunda Konstantinopolis'i fetheden ve Bizans hükümdarlığını ve kültürünü yok eden bir sultanı tasvir etmiştir. Bu da üstünlüğü ve gücü elinde tutan Fatih Sultan Mehmet'in Avrupa ve Avrupalı gözünde resmedilmesi anlamına gelmektedir. İki tablonun ortak özelliği olarak Fatih'in duygularını belli etmeyen bir tavırda çizildiği ve herhangi bir yüz ifadesine yer verilmediği görülmektedir. Ancak bununla beraber, Gentile Bellini tarafindan resmedilen portre, Fatih Sultan'ın gerçek bir görüntüsü olmayabilir. Çünkü, 1480'li yıllarda II. Mehmet'in hasta yatağında olduğu bilinmektedir ve bu nedenle Bellini'nin Sultan'1 görerek portreyi yapmış olması düşük bir ihtimaldir. Sinan Bey'e atfedilen tablonun ise Gentile Bellini'nin tablosundan dönüştürüldüğü bilinmektedir. Ve belki de bu yüzden Sinan Bey'e atfedilen tabloda Sultan'ın yüzü ifadesiz bir şekilde resmedilmiş ve iki tablo arasında çok fazla benzerlik yer almıştır.

Sonuç olarak, Gentile Bellini ve Sinan Bey/Şiblizade Ahmed'in tabloları kullanılan materyal temelinde renkler ve objeye dayanmaktadır. Bu tablolarda yer alan bütün özelliklere bakıldığında sanatçı ve resim arasında kutsal bir sınır vardır. Tablo var olan maddi zenginliği içerisinde yorumlanabilirken aynı zamanda sahip olduğu şuur içinde her zaman canlı kalmayı başaracaktır. Bir resmin sahip olduğu şuur onun fiziksel varlığıdır. Sanat eserinin içerisinde sahip olduğu yan anlamlar daima diğer insanlar için sır olarak kalacaktır. Bu doğrultuda, Fatih Sultan Mehmet Portresi ve Gül Koklayan Fatih Sultan Mehmet Portresi sahip oldukları belleği var oldukları cismani hâlleriyle taşımaktadırlar. $\mathrm{Bu}$ iki tablo sahip oldukları bakış açılarıyla Fatih Sultan Mehmet'in önemini ortaya koymaktadır. Ayrıca, Avrupalı bir ressamın yaptığı portre üzerinden yerel sanatçıya nasıl ilham kaynağı olduğunu göstermesi açısından da oldukça değerlidir.

Bu çalışmada benzer ve farklı yönleri açısından iki tablo ele alınmış ve aynı zamanda her birinin özelinde önemi değerlendirilmiştir. Ayrıca her iki tablonun yapıldığ tarihten bugüne kadar getirdikleri hafızanın önemine değinilmiştir. Son olarak, Gentile Bellini'nin tablosunun ve Şiblizade Ahmed'in tablosunun farklı sosyal, kültürel ve tarihsel tutumları içinde nasıl yapılandırıldıkları incelenmiştir. 


\section{Introduction}

Mehmet, called Fatih, conqueror,

is sniffing a rose,

savoring its scent: that is to him

like poetry, Greek logic,

like the fields outside Vienna

in springtime, like Europe, like the sweet

necks of princes. ${ }^{1}$

This paper examines the painting of Mehmet II, which was painted by Sinan Bey/ Şiblizade Ahmed based on the painting by Gentile Bellini. Those works of art show Mehmet the Conqueror in the same perspective by using different materials and styles of painting. Mehmet II is depicted as the Conqueror of Constantinople in this painting and the painting also includes concepts of Ottoman culture. This paper illustrates the ways in which particular Western elements of art commingled with traditional Turkish art imagery to depict the Sultan's power over Constantinople.

Paintings are based on material with colours and objects used in the artists' view. All properties possess a sacred boundary between the artist and the painting. The painting might be interpreted by its material wealth, but the connotations always remain a secret for other people. However, matter is always alive with its consciousness. A painting's consciousness is its physical entity. As Rudy Rucker said, every object or process is a computation [...] the world made computations. ${ }^{2}$ It can be said that the paintings, Mehmet the Conqueror Smelling a Rose and Painting of Mehmet II, carry their own memories with their live materiality.

Sultan Mehmet the Conqueror was interested in $\operatorname{art}^{3}$ and had lecturers who taught him about art. He was also a follower of humanist intellectual tendencies. The Conqueror of Constantinople followed architectural design, bronze casting, and pictorial perspective. He specifically focused on Italy and Italian artists. ${ }^{4}$ Mehmet the Conqueror was not the only sultan interested in art: Mehmet's son Bayezid II also invited Leon-

1 Lillias Bever, "Mehmet Sniffing a Rose", Poetry 182 (2003), 273.

2 Rudy Rucker, "Everything Is Alive", Progress of Theoretical Physics Supplement 173 (2008), 365.

3 Mehmet the Conqueror was curious about art and also studied foreign languages, geography, and philosophy, interested in astronomy, ancient Greek and Byzantine works, and architect. Costanzo de Ferrara, Bertoldo di Giovanni, Matteo de Pasti did medallion portraits of the Sultan, See John Freely, The Grand Turk (Apple Books), (New York: The Overlook Press, 2009).

4 Elizabeth Rodini, "The Sultan's True Face? Gentile Bellini, Mehmet II, and the Values of Verisimilitude”, The Turk and Islam in the Western Eye, 1450 - 1750: Visual Imagery before Orientalism, ed. James G. Harper, (Burlington: Ashgate Publishing Company, 2011), 25. 
ardo da Vinci and Michelangelo di Lodovico Buonarroti Simoni in 1502 and 1506 to Istanbul. Nevertheless, Bayezid II was more interested in engineering ventures and wanted to construct a bridge over the Golden Horn to link the Muslim and European Quarters of the Ottoman capital. During the $16^{\text {th }}$ century, no figural artists were invited to the Ottoman capital. In 1578, Sokullu Mehmet Pasha tried to create an album of imperial portraits, but in 1575 and 1577, two books with images of the Ottoman sultans were published by Paolo Giovio..$^{5}$ During the last decades of Mehmet Sultan's life, he had awareness of many Italian and Near Eastern artists. There is not any physical iconography of other Sultans in the Ottoman Empire except for that of Sultan Mehmet the Conqueror and Suleyman the Magnificent. ${ }^{6}$ For this reason, the portraits of Sultan Mehmet possess a special place in the history of Ottoman art. In this paper, these paintings' (Mehmet the Conqueror Smelling a Rose and Painting of Mehmet II) long past will be explained in their social, cultural, and historical attitudes to materiality.

\section{Sinan Bey, Mehmet the Conqueror Smelling a Rose/Mehmet II Smelling a Rose}

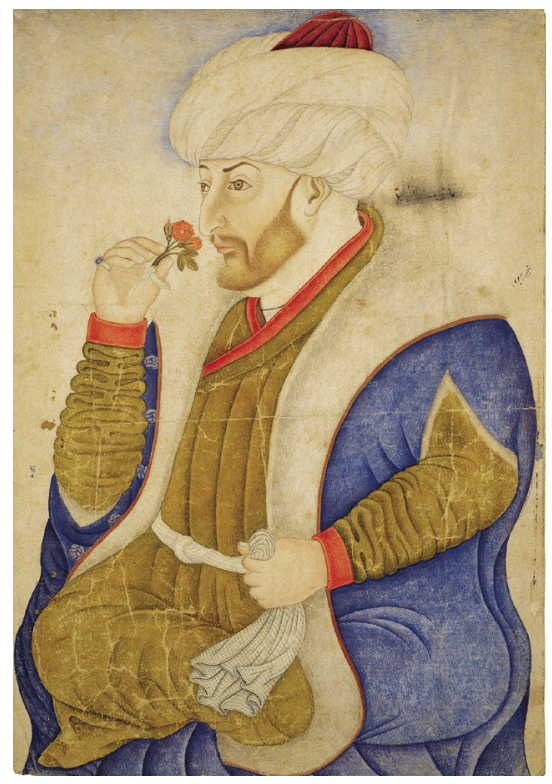

F. 1. Sinan Bey or Şiblizade Ahmed Çelebi, Mehmet the Conqueror Smelling a Rose, c. 1480.

(Directorate of National Palaces, Topkapı Palace, TSMK.H.2153, y.10a)

5 Julian Raby, "The Serenissima and the Sublime Porte: Art in the Art of Diplomacy, 1453-1600", Venice and the Islamic World 828 - 1797 (New Haven: Yale University Press, 2007), 107-109. The portrait collection of Italian Paolo Giovio possesses diversity with its non-Italian men and women from his distant past and to his present, which is made up of minor or unknown artists in Italy. Giovio made portraits of the Ottoman Sultans such as Mehmet I, Sultan Selim I, Murad I, Beyazıd II etc., see Nassim Rossi, "Italian Renaissance Depictions of the Ottoman Sultan: Nuances in the Function of Early Modern Italian Portraiture", (PhD. Diss, Columbia University, 2013).

6 Stefano Carboni, "Catalogue of Exhibited Works", Venice and the Islamic World 828-1797 (New York/New Haven and London: The Metropolitan Museum of Art/Yale University Press, 2007), 303. 
Mehmet the Conqueror Smelling a Rose (F. 1) painting's artist is uncertain, but the two in this regard it has been suggested, Sinan Bey and Şiblizade Ahmed Çelebi. The portrait was probably painted around the $1480 \mathrm{~s}$, however, the exact date is still unknown. The miniature painting was painted on a paper with an unusual scale; it measures 390x270 mm. Mehmet the Conqueror is seated cross legged, holding a red rose in his right hand and a handkerchief in his left hand. He wears a furred kaftan, a dress, and a turban with a red kulah. His painting Mehmet II Smelling a Rose is now exhibited in Topkap1 Palace, Istanbul.

Sinan Bey was the court painter of Sultan Mehmet II. Sinan Bey was probably trained by Maestro Pavli (Paolo da Ragusa) ${ }^{7}$ a European master. ${ }^{8}$ He was worked on miniature paintings on paper such as Mehmet II Smelling a Rose. As an Ottoman court painter, Sinan Bey synthesized Eastern and Western cultures with his pupils such as Şiblizade Ahmed and mediated the translation of them into native culture. ${ }^{9}$ The book, Menakıb-1 Münevveran, mentions that Şiblizade Ahmed was the best portrait (şebih) painter among the most important artists. ${ }^{10}$ There is no further information about Sinan, but it is known that he was sent to Venice in 1480 as the ambassador of the Ottoman Empire. Sinan Bey was influenced by Italian paintings on his works. Sinan Bey's painting transforms into Gentile Bellini's painted portrait into a seated royal image. ${ }^{11}$ Some sources claim that the portrait of Mehmet the Conqueror was painted by Sinan Bey, it seems more possible Şiblizade Ahmed is the main creator of the painting. ${ }^{12}$ Şiblizade was adept at painting portraits and could produce similar work to Bellini. However, Şiblizade learned the European style of painting from a secondary source, Sinan Bey. However, even though there is not exact information about the creator, the painting has been attributed to Sinan Bey.

7 Gelibolulu Mustafa Ali, Menakıb-ı Hünerveran: Hattatların ve Kitap Sanatçılarının Destanları, ed. Müjgan Cunbur (İstanbul: Büyüyenay Yayınları, 2012), 153.

8 Mustafa Ali, Menakıb-ı Hünerveran, 153.

9 Gülru Necipoğlu, "Visual Cosmopolitanism and Creative Translation: Artistic Conversations with Renaissance İtaly in Mehmed II's Constantinople", Muqarnas 29 (2012), 4.

10 Mustafa Ali, Menakıb-l Hünerveran, 153.

11 Gülru Necipoğlu, "From Byzantine Constantinople to Ottoman Konstantiniye: Creation of a Cosmopolitan Capital and Visual Culture Under Sultan Mehmed II", From Byzantion to Istanbul: 8000 Years of a Capital City, (İstanbul: Sakıp Sabancı Müzesi, 2010), 264-276.

12 The Sultan's portrait, Mehmet II Smelling a Rose, reattributed to Sinan Bey's pupil Şiblizade Ahmed by Julian Raby, Necipoğlu, and Bağcı, see Julian Raby, El Gran Turco: Mehmed the Conqueror as a Patron of the Arts of Christendom (London: Oxford University, 1980); Necipoğlu, "Visual Cosmopolitanism and Creative Translation”, 1-81; Serpil Bağcı etc., Osmanlı Resim Sanatı (İstanbul: T.C. Kültür ve Turizm Bakanlığı Yayınları, 2006). Şiblizade was more talented European portrait painter, even though Sinan Bey was the master of Şiblizade Ahmed. For these reasons, I prefer to use Şiblizade Ahmed as the artist of the painting, Mehmet II Smelling a Rose, in this work. 


\section{Gentile Bellini, Painting of Mehmet II}

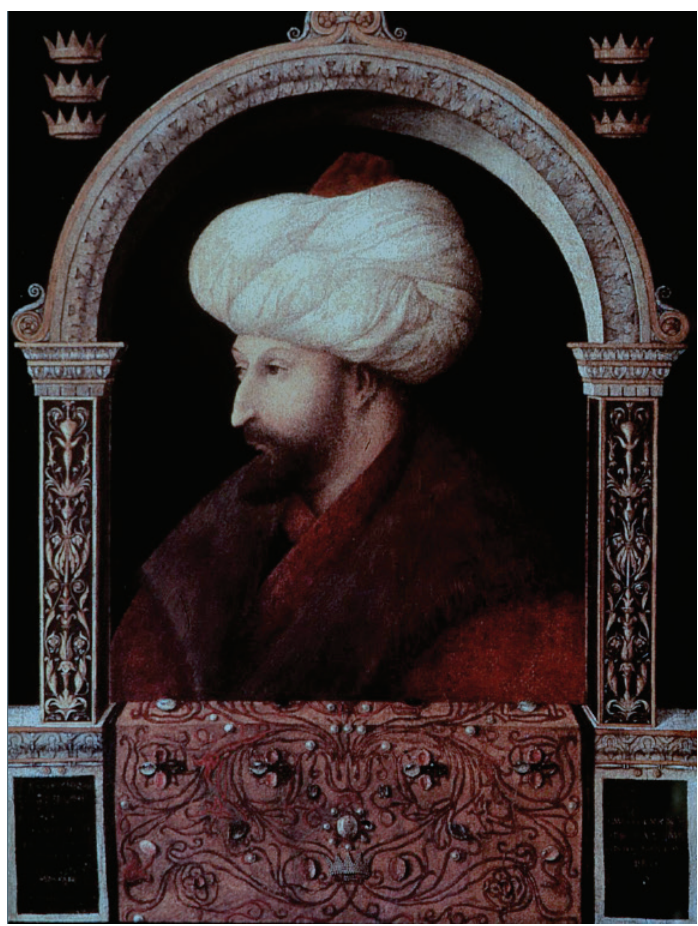

F. 2. Gentile Bellini, The Sultan Mehmet II, 1480, The National Gallery, London. (Gülru Necipoğlu, "Visual Cosmopolitanism and Creative Translation: Artistic Conversations with Renaissance Italy in Mehmed II's Constantinople", 34)

In 1479, the Ottoman Empire took control of the Ionian Islands. At that time, Italy was in the midst of a crisis. In the summer of 1479, the Ottomans proposed an agreement to Venice, and the Signoria accepted the alliance, thus ensuring he could protect Venice from an enemy region, Florence. The Signoria also reassured the Sultan's rights in seizing Brindisi, Taranto, and Otranto. ${ }^{13}$ Eventually, the Ottoman Empire was not able to take Venice, but it was obvious that the Venetians sent gifts to him to protect their rights. In other words, they figured out the Ottomans' strategy which was to capture Italy step by step. Since they recognized the danger, they tried to defend themselves by different means, such as gifts or the alliance. Venice not only assured itself, but also Florence tried to keep its own land safe against the Ottomans with gifts. Certainly, Florence and Venice were not allying with one another, and the Signoria of Venice made an agreement with the Ottoman Empire to avoid a confrontation with Florence. The Italian peninsula, including Florence, Milan and Venice, was threatened by powerful empires,

13 Franz Babinger, Mehmed the Conqueror and His Time, trans. Ralph Manheim, (New Jersey: Princeton University Press, 1978), 390. 
the French, The Ottoman, and the Spanish, with political and diplomatic systems and strategies. ${ }^{14}$ Venice had an important position between the East and West because of its strong mercantile character. Thus, it had a special relationship with the Islamic world. For example, the Ottoman Empire had Venetian commercial treaties. ${ }^{15}$ The conquest of Constantinople helped to link different networks of international trade. ${ }^{16}$

In 1479 Sultan Mehmet sent an envoy with a letter to Venice requesting a good painter. Even though Sultan did not give the name of any artists, he was seeking an artist recommended by the leaders of Venice. Gentile Bellini was sent to Istanbul for sixteen months. ${ }^{17}$ It is obvious that the Venetians sent Bellini as a gift to Sultan Mehmet to protect their rights in the bad condition of their country. Mehmet II did not specify Bellini, however he desired different skilled artists and craftsmen: a painter, a sculptor, and a builder. The Sultan might have wanted to begin a new architectural project in his new palace. ${ }^{18}$ Bellini visited Istanbul as the cultural ambassador of the Venetian Republic. Ambassadors came to visit Venice from the Ottoman lands and gave special gifts to Venetian artists, such as patterned silks and gilded glass. Gentile Bellini did not visit any other near Eastern cities except Istanbul. When he was in Istanbul between 1479 and 1481, he made a number of studies of Ottoman Costumes, monuments, luxury goods, exotic animals, all of which became the point of reference for his canvas of St. Mark Preaching in Alexandria for the scuola. ${ }^{19}$

Gentile Bellini's Painting of Mehmet II (F. 2) is regarded as a Western European image of Turkish culture. The painting started in Istanbul and was later completed in Venice. This circulation caused a shift in audience from the West to the East. Though the date is uncertain, the painting was probably painted in 1480 .

Traditional imperial portraiture had existed for four centuries during the Ottomans, which began at the time of Mehmet II. ${ }^{20}$ In the portrait by Gentile Bellini, the Sultan is shown in a three-quarter view beneath a marble arch and a jewel-encrusted embroidered textile. Renaissance architecture spread from Florence to Europe, which characteristically was dominated by rounded shapes in harmony. ${ }^{21}$ So, the arch in

14 Daniel Goffman, "Negotiating with the Renaissance state: The Ottoman Empire and the new Diplomacy", The Early Modern Ottomans: Remapping the Empire, ed. Virginia H. Aksan and Daniel Goffman (New York: Cambridge University Press, 2007), 61.

15 Catarina Schmidt Arcangeli, "Orientalist Painting in Venice, $15^{\text {th }}$ to $17^{\text {th }}$ Centurie", Venice and the Islamic World 828 - 1797 (New Haven: Yale University Press, 2007), 122.

16 Nükhet Varlık, "Conquest, Urbanization and Plague networks in the Ottoman Empire, 1453-1600", The Ottoman World, ed. Christine Woodhead (New York: Routledge Taylor \& Francis Group, 2012), 253.

17 Rodini, The Sultan's True Face, 24.

18 Julian Raby, "The Serenissima and the Sublime Porte: Art in the Art of Diplomacy, 1453-1600”, 107.

19 Schmidt Arcangeli, Orientalist Painting in Venice, 128.

20 Günsel Renda, "The Ottoman Court and Sultanic Portraiture", Orientalists at the Ottoman Palace (İstanbul: TBMM Milli Saraylar Daire Başkanlığı, 2006), 33.

21 Halil İnalcık, Rönesans Avrupası Türkiye'nin Batı Medeniyetiyle Özdeşleşme Süreci (İstanbul: Türkiye İş 
Bellini's work is emblematic of a typical feature of Renaissance architecture. Mehmet II appears in a red kaftan, a dark brown fur pelt, and a white turban wrapped around a red taj. His headdress and position represent that he is a Muslim. The painting demonstrates the Sultan's sharply pointed nose and beard, while his turban, with big contours, creates conflict. There are inscriptions on the left and right sides of the parapet and phrases which say Mehmet II is Victor Orbis, Conqueror of the World. The date of this inscription is November 25, 1480 which is located at the bottom of the painting. ${ }^{22}$ The painting of the Sultan was created by Bellini in Istanbul, but Bellini returned to Venice towards the end of 1480 with a recommendation letter from Mehmet II to be given to the Venetian Senate and the Doge of Venice. ${ }^{23}$ Bellini went to Constantinople in 1479 and returned to Venice in $1480 .{ }^{24}$ Upon his arrival in Venice, Gentile Bellini completed the portrait. The Painting was returned to İstanbul after Bellini signed the Sultan's painting. Yet, Mehmet the Conqueror died, and Bellini's work appeared in different museums in Europe after being sold in the İstanbul bazaar by the Sultan's son, Bayezid II. ${ }^{25}$ In addition, Sultan Mehmet's son Bayezid, who was known to be very religious, sold the painting due to its Christian imagery. The painting was brought to Venice in the early $16^{\text {th }}$ century and remained there until ca. $1865 .{ }^{26}$ The painting was hung in the private space of a Venetian palace. ${ }^{27}$ This indicates that Mehmet the Conqueror and Bayezid II had a completely different view of the world and understanding of art. The painting of the Sultan is $69.9 \times 52.1 \mathrm{~cm}$ which represents his glorious nature. The famous painting portrait of Sultan Mehmet is now in the National Gallery, London.

\section{Discussion}

The Venetian master Gentile Bellini had created a new iconography for the Sultans. Bellini's creation, Painting of Mehmet II, represents the Sultan's military courage. There are seven crowns which symbolize the Ottoman Dynasty ${ }^{28}$, and Mehmet II is

Bankası Kültür Yayınları, 2013), 78.

22 Carboni, "Catalogue of Exhibited Works", 303.

23 Nurullah Berk, "Fatih Sultan Mehmet ve Venedikli Ressam Gentile Bellini”, Ankara Üniversitesi Ilahiyat Fakültesi Dergisi 2/2 (1953), 152.

24 Gentile Bellini was situated in Constantinople from the September 1479 to the end of November 1480, see George F. Hill, "Medals of Turkish Sultans", Numismatic Chronicle 6 (1926), 288. Bellini spent about sixteen months in Constantipole as the request of Fatih, see Rodini, The Sultan's True Face, 24.

25 Franz Babinger, Mehmed the Conqueror and His Time, trans. Ralph Manheim (New Jersey: Princeton University Press, 1978), 379; Stefano Carboni, "Catalogue of Exhibited Works", Venice and the Islamic World 828-1797 (New York/New Haven and London: The Metropolitan Museum of Art/Yale University Press, 2007), 303; Halil İnalcık, The Ottoman Empire: The Classical Age, 1300-1600 (Istanbul: Yapı Kredi Yayınları, 1995), 30; Julian Raby, "Oyun Başlıyor", Padişahın Portresi Tesavir-i Al-i Osman (İstanbul: Türkiye İș Bankası Kültür Yayınları, 2000), 72; Ahmed Refik, Fatih ve Bellini, trans. Önder Kaya (İstanbul: Yeditepe Yayınları, 2006), 15.

26 Carboni, "Catalogue of Exhibited Works", 303.

27 Rodini, The Sultan's True Face, 23.

28 Ottoman sultans respectively Osman Gazi, Orhan Gazi, Murad I, Bayezid I, Mehmet I, and Murad II. 
the $7^{\text {th }}$ sultan in the imperial line..$^{29}$ Such rendering of three-dimensional space was not yet seen among Ottoman court artists but was apparent in the high art of Italian Renaissance painting. Gentile Bellini learned to use a site for Latin inscriptions and to use a parapet as a distance between viewer and sitter from Roman stelae and tombstones. The arch represents a universal symbol of victory appropriate for the sultan who conquered Constantinople in 1453. The marble arches were used in Venetian ecclesiastical architecture and in paintings such as Bartolomeo Vivarini's Virgin and Child in the Museo di Capodimonte, Naples. ${ }^{30}$ For these reasons, it is unclear why Mehmet II requested this kind of arch in his portrait. In my opinion, he wanted to use such a stylish form to represent himself as the new ruler of Constantinople. It is also possible that the arch can be seen as representative of the city gate of Constantinople. ${ }^{31}$ In this way, he intended to demonstrate his power throughout Constantinople.

The background of the painting is dark, but the Sultan appears with a red robe and a white turban. This may indicate his effort to communicate his status as the conqueror of Constantinople, and that a dark century had ended. It is obvious that after the conquest of Constantinople, the middle age had passed, and a new age had begun. Thus, the darkness represents the Byzantine and he demonstrates the Ottoman Empire, his conquest, and Istanbul. Furthermore, this picture might emphasise religious aspects, such as the black background possibly representing Christianity, and Mehmet the Conqueror, indicating Islam. This is could be because Constantinople became Istanbul, and the area of Byzantine became an Islamic territory after Mehmet II. The painting of Mehmet II, therefore, also possesses religious and political standpoints.

Sultan Mehmet's preference for Italian artists was clearly personal, as, after him, there was no such attention shown to these artists. However, it is not clear what the role of a portrait painted by Bellini would be in the Ottoman court. It is known that in Italian courts, the sitting pose indicated a message of powerful authority; the composition of the painting and symbols carried power and local sovereignty. Mehmet specified his imperial force clearly. ${ }^{32}$ Of course, Bellini's artistic and cultural accumulation are the factors that make the painting more prominent.

29 Schmidt Arcangeli, Orientalist Painting in Venice, 136.

30 Carboni, "Catalogue of Exhibited Works", 303.

31 The arch in the painting, to my of thinking, actually gives the feeling about the existence of the wall along the two sides of the gate. According to Maria Pia Pedani, the arch is the gate or kap 1 formally represents the renaissance style gate of the Venetian Church of San Zaccaria but its meaning is the third court of the Topkap Palace. Through this statement, in my opinion that the gate in the painting should surround by walls, in which the area protected Constantinopole by the Sultan Mehmet II. Maria Pia Pedani, "The Portrait of Mehmet II: Gentile Bellini, the making of an Imperial Image", 10th International Congress of Turkish Art, ed. François Déroche, Charles Genequand, Günsel Renda, and Michael Rogers (Geneva: Fondation Max Van Berchem, 1999), 555.

32 Rodini, The Sultan's True Face, 28. 
In Bellini's painting, Mehmet's known aesthetic art interests are displayed by the Italian artist through his copying of the visual world of the Sultan. According to Elizabeth Rodini, Bellini's portrait is not merely an Ottoman adaptation of an Italian pictorial genre; furthermore, from Mehmet's perspective, the portrait that Bellini painted was not in appearance a truthful documentation of the foreignness, as it has generally been interpreted in Western scholarship. ${ }^{33}$

The Sultan's portrait conveys a political message. Gentile Bellini visited Sultan Mehmet's court in 1479. The Venetians battled with the Ottomans between 1463 and 1479. Therefore, it is obvious that his visit and his painting carried a political message between Italy and the Ottoman Empire. The Venetians tried to have a good relationship with the Sultan by giving gifts. In the time of Sultan Mehmet, Gentile Bellini was known for his work in retracto, which means re-tracing, mapping and portraiture share, in Italy. For this reason, he was chosen as a painter for Sultan's court. ${ }^{34}$ Gentile did not only satisfy the sultan's demand but also exceeded the boundaries. ${ }^{35}$ Bellini's portrait might not be a true image of the Sultan. The painting of the Sultan was started in Istanbul but was eventually finished by Gentile Bellini in Venice. It is not certain whether the Conqueror of Constantinople ever saw his painting because he was sick while this work of art was being produced. It is not clear whether the face depicted exactly resembles his own face because, in 1480, Mehmet II was sick in his bed. However, in the painting he looks lively and healthy. Certainly, Gentile Bellini used his imagination to paint Mehmet the Conqueror.

In the painting, the Sultan appears in a white turban and robe in a dark background under an arch. The inclusion of the arch in the painting is also questionable because, in general, Gentile Bellini did not use arches in the portraits he painted. Therefore, it is a unique scene that the Sultan appears under an arch. This distinction might demonstrate the arch of Constantinople, which at that time had been given over to Mehmet the Conqueror. The arch might have been included by the artist or at the request of the Sultan. It is certain that the arch is related to the victory of Mehmet II because the rest of the painting depicts his achievements. For instance, there are crowns on three sides of the painting which stand for the lands of Asia, Trebizond, and Greece. These crowns may have an intertwined meaning; thus, they do not only represent the Sultan's success but also indicate his ancestors. ${ }^{36}$ Furthermore, the number of crowns, seven, in the jewel-encrusted embroidered textile signifies that Mehmet II was the $7^{\text {th }}$ Sultan

33 Rodini, The Sultan's True Face, 29.

34 Rodini, The Sultan's True Face, 33.

35 Antonia Gatward Cevizli, "Bellini, Bronze and Bombards: Sultan Mehmed II's Requests Reconsidered," Renaissance Studies 28 (2014), 750.

36 For the hypothesis that the ancient sovereign's power is derived from his ancestors and an Ottoman Sultan inherited the throne who is visited the ancient ruler's tomb. So, the six crowns emblematize the Sultan's ancestors, see Pia Pedani, "The Portrait of Mehmet II," 556. 
of the Ottoman Empire. In addition, the other six crowns might also be interpreted as representing the marks that the previous sultans had left as the touchstones of the Ottoman Empire. The triple crowns also appear on the medallic portrait of the Sultan by Gentile Bellini, which represent the three kingdoms of the Sultan's Empire, Greece, Trebizond, and Asia. These triple crowns were used as three kingdoms in place of the Sultan's victory over all the allied Western and Eastern Powers for sixteen-year long Veneto-Ottoman war. ${ }^{37}$ In the medallic portrait of the Sultan's posture, his turban and dress bear the same characteristics of the painting. However, Mehmet II is depicted as being younger in the medallic portrait by Bellini. ${ }^{38} \mathrm{~A}$ typical example of renaissance humanism includes the images of the historical influence of military leaders and the Italian influence in both the form and acceptance of the sultan's patronage. ${ }^{39}$

The darkness of the background of the painting might represent the Byzantine era as a dark period, but the Sultan is clearly the main figure, which indicates the triumph of the Ottoman Empire over the old Byzantine Empire. At the same time, two words in the text on the left side of the painting are noteworthy. The meaning of these two words are "the Conqueror of the World." Fatih conquered Constantinople as a Muslim Sultan. Constantinople was taken from a Christian-based state and placed completely into the hands of a Muslim-based country. This was not only a change for Constantinople but also a change for the world as well as the beginning of a new era. From this point of view, it may be considered that Istanbul was the centre of the world for Mehmet II. It can be also assumed that Mehmet the Conqueror wanted to show himself to the intended audience, the West, as the Conqueror and to usher in the new era by using a visual language which demanded an Italian artist in the Western style.

However, the impression of the West or the influence of the East on these two paintings is rather limited. Gentile's portrait is more related to Western art and the painting by Şiblizade Ahmed is evocative of Bellini's portrait but has identifying traces of eastern art. In both paintings, the Sultan Mehmet wears a kaftan, a dress, and a turban. The Conqueror demonstrates almost the same style of apparel with different colours and perhaps materials. The raw materials which were processed to be used in the royal workshops in the Ottoman Empire were silk and thread used in the making of clothes for the sultans. ${ }^{40}$ The dress of Mehmet the Conqueror under the fur is called

37 Necipoğlu, "Visual Cosmopolitanism and Creative Translation", 34.

38 Berk, Fatih Sultan Mehmet ve Venedikli Ressam Gentile Bellini, 152. Raby and Necipoğlu believe that the medal of Mehmet II is created in 1480 before Gentile Bellini returned to Venice, see Julian Raby, "Pride and Prejudice: Mehmed the Conqueror and the Italian Portrait Medal," Studies in the History of Art 21(1987), 171-194; Necipoğlu, "Visual Cosmopolitanism and Creative Translation", 1-81.

39 Raby, "Pride and Prejudice: Mehmed the Conqueror and the Italian Portrait Medal", 176. The four prominent medal portrait of Sultan Mehmet II's are by Gentile Bellini, Bertoldo di Giovanni, and Costanzo da Ferrara, and the so-called Tricaudet or Trieaudet, see Raby, "Pride and Prejudice: Mehmed the Conqueror and the Italian Portrait Medal", 171-194.

40 Bahattin Yaman, "Fit For the Court: Ottoman Royal Costumes and Their Tailors, from the Sixteenth to Eighteenth Century", Ars Orientalis 42 (2012), 92. 
entari in Turkish. An entari reaches down to the ankles with long, slit sleeves. ${ }^{41}$ These kinds of dresses might change depending on the person and the material used. Different materials such as cotton, silk, taffeta or fine fabrics can be used. An entari can be worn on special occasions and in daily life in the same way and is not representative of any prestige or status. In Mehmet II Smelling a Rose, Mehmet II probably wears a fur kaftan, however, the painting of Mehmet II probably represents the kaftan within full fur. Sultan Mehmet might have worn a wolf fur because the wolf was a totem animal for Turkish tribes. ${ }^{42}$ Fur over-coats stand for a symbol of Ottoman wealth and the representation of one is related to the importance of fur and the Sultans' preferences. ${ }^{43}$ However, kaftan might be the tool that demonstrates status, prestige, and personal position with its rich patterns and materials used such as brocaded silk fabrics and fur and also sometimes a lining was used. The entari and kaftan can be used together as worn by Mehmet the Conqueror in both paintings. A brief comparison of the portraits of Mehmet II shows the same fashions in his imperial wardrobe.

Şiblizade Ahmed Çelebi's painting represents the Conqueror on the throne sitting cross-legged which shows that the painting is more relevant to the traditional cultural considerations. It is possible that the Turks crouching cross-legged comes from tent culture. ${ }^{44}$ For example, portraits in medallions had members of the dynasties crouching cross-legged with three-quarters profiles and symbols such as rose in the roller timber of the Timurid period. In this painting, Ahmed's mastery of combining Italian and Timurian traditions justifies the fame that he earned a hundred years later as a portrait artist. ${ }^{45}$ In the Sultan Mehmet II, the Sultan might be sitting his cross-legged on the throne which is covered by an ornate stone textile. Bellini could have wanted to make the painting more Western with these jewels by closing the seated posture because that pose was traditionally more related to the Turks.

The Sultan's turban has a very important symbol. The Turban symbolises death; thus, the Sultan does not forget that he can die at any moment. Furthermore, the Sultans' turban looks like a tombstone, for this reason his turban is related to death. In Islam, the Prophet Muhammad is represented and symbolised by a red rose. ${ }^{46}$ Mehmet the Conqueror believed in Islam and respected the Prophet Muhammad. Muslims believe that the Prophet Muhammad's smell was like a rose. Thus, a rose as a material object can connect to the

41 Fatma Koç and Emine Koca, "The Clothing Culture of the Turks, and the Entari (Part 2: The Entari)", Folk Life: Journal of Ethnological Studies 50 (2012), 142.

42 Pia Pedani, "The Portrait of Mehmet II", 556.

43 Yaman, "Fit For the Court," 96.

44 Emel Esin, "Bağdaş ve Çökmek Türk Töresinde İki Oturuş Şeklinin Kadim İkonografisi”, Sanat Tarihi Araştırmaları III (İstanbul: İstanbul Üniversitesi Edebiyat Fakültesi Sanat Tarihi Enstitüsü, 1970), 242.

45 Julian Raby, “Oyun Başliyor”, 70.

46 Rose possesses many meanings such as love, purity, silence, etc., which is also hosting different colours within different interpreting in various cultures, see Zeynep Alsancak, "Türk Kültüründe Gülün Simgesel Anlamları", (M. A. Thesis, Istanbul University, 2017). 
Prophet. In Mehmet II smelling a rose, Sultan Mehmet carries a white handkerchief. The background of the painting is white, and the Sultan appears with a green dress, a blue robe and a white turban. All the colours represent Islam. This may indicate his effort to communicate that he is the caliph of the Muslim world. During that period, the Ottoman Empire held the title of caliph in its territory. Consequently, the painting quietly represents Islam.

Both Paintings represent Mehmet the Conqueror with different aspects. The paintings demonstrate the Sultan's sharply pointed nose and beard; however, Mehmet II has a more distinctive black beard in Bellini's painting. In addition, the marble arch appears with a jewel encrusted embroidered textile, but it is uncertain whether it is gold or made from another material. However, its colour is gold therefore it might be assumed to be gold. Men do not carry gold and do not carry jewelry as an Islamic rule; thus, these ornaments are represented beneath the arch instead of displayed on Mehmet the Conqueror. This jewel encrusted embroidered textile might represent Byzantine as well as wealth and pride. Sultan Mehmet conquered Constantinople and all Byzantine values were replaced by a different culture and religion. Sultan Mehmet not only became the conqueror for the Ottoman Empire, but also took over the legacy of Byzantine. For this reason, this ornament and gold colour might represent values of the Byzantine Empire from a different point of view. However, the jewel encrusted embroidered textile might have been engraved on wooden material. In the Sultan Mehmet II, gold is used as an ornament, but it is not shiny. If gold is representative of Byzantine, it might be interpreted as symbolising that Byzantine collapsed. Furthermore, in both paintings, the Sultan has a very insensitive facial expression. Bellini's portrait might not be a true image of the Sultan because in 1480 Mehmet the Conqueror was sick and Bellini finished his work in Venice. Sinan Bey transformed his painting from Bellini's painting, for this reason, Sultan Mehmet does not express any facial gestures in both paintings.

The surface of Bellini's painting is damaged, which draws direct attention to the portrait of Sultan Mehmet. The picture does not give equal emphasis to all aspects of the painting, perhaps because of the damage to the surface or the focus on Mehmet's glory. The surface of Bellini's painting is damaged and Sinan Bey's painting is also probably damaged because there is a black spot in the upper right corner of the painting.

\section{Conclusion}

Mehmet the Conqueror was interested in the art of other countries. Italy especially showed their respect to the Conqueror of Constantinople by giving valuable handmade gifts. They sought to protect their rights, and art became a safeguard against the Ottoman Empire, an example of which is the Sultan Mehmet II by Gentile Bellini. Works of art by foreign painters influenced local painters and allowed them to paint like foreign painters such as Sinan Bey and his pupil Şiblizade Ahmed whose work was Mehmet 
the Conqueror Smelling a Rose. Both paintings represent different aspects by different artists. Each artist has a different cultural background that influences their paintings. The artwork of Gentile Bellini and Şiblizade look similar, however they display different points of view of Mehmet the Conqueror within their own cultural backgrounds.

This paper has illustrated the features of the paintings of Mehmet the Conqueror by Gentile Bellini and Şiblizade Ahmed. These works of art indicate that the different aspect of artists present the importance of Mehmet II by using different materials. In addition, this paper showed how a foreign artist provided inspiration for a local artist. The unique elements in these works of art have been explained in accordance with each painting. In this study, the paintings were explained based on the objects and properties used. They are also configured with their own long history and different social, cultural, and historical attitudes to materiality.

Peer-review: Externally peer-reviewed.

Conflict of Interest: The author has no conflict of interest to declare.

Grant Support: The author declared that this study has received no financial support.

Hakem Değerlendirmesi: Dış bağımsız.

Çıkar Çatışması: Yazar çıkar çatışması bildirmemiştir.

Finansal Destek: Yazar bu çalışma için finansal destek almadığını beyan etmiştir.

\section{References/Kaynakça}

Ahmed Refik. Fatih ve Bellini. Translated by Önder Kaya. İstanbul: Yeditepe, 2006.

Alsancak, Zeynep. “Türk Kültüründe Gülün Simgesel Anlamları”. M. A. Thesis, İstanbul University 2017.

Bever, Lillias. "Mehmet Sniffing a Rose". Poetry 182 (2003): 272-273.

Babinger, Franz. Mehmed the Conqueror and His Time. Translated by Ralph Manheim. New Jersey: Princeton University Press, 1978.

Bağcı, Serpil, Filiz Çağman, Gürsel Renda, and Zeren Tanındı. Osmanlı Resim Sanatı. İstanbul: T.C. Kültür ve Turizm Bakanlığı Yayınları, 2006.

Berk, Nurullah. "Fatih Sultan Mehmet ve Venedikli Ressam Gentile Bellini”. Ankara Üniversitesi İlahiyat Fakültesi Dergisi 2/2 (1953): 143-160.

Carboni, Stefano. "Catalogue of Exhibited Works". Venice and the Islamic world, 828-1797. New Yok/ New Haven and London: The Metropolitan Museum of Art/Yale University Press, 2007, 294-350.

Cevizli, Antonia Gatward. "Bellini, Bronze and Bombards: Sultan Mehmed II's Requests Reconsidered”. Renaissance Studies 28 (2014): 748-765.

Directorate of National Palaces, Topkap1 Palace. TSMK. H.2153, y.10a. Mehmet the Conqueror Smelling a Rose.

Esin, Emel. "Bağdaş ve Çökmek Türk Töresinde İki Oturuş Şeklinin Kadim İkonografísi”. Sanat Tarihi Araştırmaları III. İstanbul: İstanbul Üniversitesi Edebiyat Fakültesi Sanat Tarihi Enstitüsü, 1970, 231-242.

Freely, John. The Grand Turk. (Apple Books) New York: The Overlook Press, 2009. 
Gelibolulu Mustafa Ali. Menakıb-ı Hünerveran: Hattatların ve Kitap Sanatçılarının Destanları. Edited by Müjgan Cunbur. İstanbul: Büyüyenay Yayınları, 2012.

Goffman, Daniel. "Negotiating with the Renaissance State: The Ottoman Empire and the New Diplomacy". The Early Modern Ottomans: Remapping the Empire. Edited by Virginia H. Aksan and Daniel Goffman. New York: Cambridge University Press, 2007, 61-75.

Hill, George F. "Medals of Turkish Sultans”. Numismatic Chronicle 6 (1926): 287-298.

İnalcık, Halil. Rönesans Avrupası Türkiye’nin Batı Medeniyetiyle Özdeşleşme Süreci. İstanbul: Türkiye İş Bankası Kültür Yayınları, 2013.

İnalcık, Halil. The Ottoman Empire: The Classical Age, 1300-1600. İstanbul: Yap1 Kredi Yayınları, 1995.

Koç, Fatma and Emine Koca. "The Clothing Culture of the Turks, and the Entari (Part 2: The Entari)”. Folk Life: Journal of Ethnological Studies 50 (2012): 141-68.

Necipoğlu, Gülru. "From Byzantine Constantinople to Ottoman Konstantiniye: Creation of a Cosmopolitan Capital and Visual Culture Under Sultan Mehmed II." From Byzantion to Istanbul: 8000 Years of a Capital City. İstanbul: Sakıp Sabanc1 Müzesi, 2010, 262-277.

Necipoğlu, Gülru. "Visual Cosmopolitanism and Creative Translation: Artistic Conversations with Renaissance İtaly in Mehmed II's Constantinople”. Muqarnas 29 (2012): 1-81.

Pedani, Maria Pia. "The Portrait of Mehmet II: Gentile Bellini, the Making of an Imperial Image". 10th International Congress of Turkish Art. Edited by François Déroche, Charles Genequand, Günsel Renda, and Michael Rogers. Geneva: Fondation Max Van Berchem, 1999, 555-558.

Raby, Julian. El Gran Turco: Mehmed the Conqueror as a Patron of the Arts of Christendom. London: Oxford University, 1980.

Raby, Julian. "Oyun Başlıyor”. Padişahın Portresi Tesavir-i Al-i Osman. İstanbul: Türkiye İş Bankası Kültür Yayınları, 2000, 64-95.

Raby, Julian. "Pride and Prejudice: Mehmed the Conqueror and the Italian Portrait Medal." Studies in the History of Art 21 (1987): 171-194

Raby, Julian. "The Serenissima and the Sublime Porte: Art in the Art of Diplomacy, 1453-1600". Venice and the Islamic World 828 - 1797. New Haven: Yale University Press, 2007, 90-120.

Renda, Günsel. "The Ottoman Court and Sultanic Portraiture". Orientalists at the Ottoman Palace. İstanbul: TBMM Milli Saraylar Daire Başkanlığı, 2006, 33-42.

Rodini, Elizabeth. "The Sultan's True Face? Gentile Bellini, Mehmet II, and the Values of Verisimilitude." The Turk and Islam in the Western Eye, 1450 - 1750: Visual Imagery before Orientalism. Edited by James G. Harper. Burlington: Ashgate Publishing Company, 2011, 21-41.

Rossi, Nassim. "Italian Renaissance Depictions of the Ottoman Sultan: Nuances in the Function of Early Modern Italian Portraiture”. PhD. diss., Columbia University, 2013.

Rucker, Rudy. "Everything Is Alive." Progress of Theoretical Physics Supplement 173 (2008): 363-370.

Schmidt Arcangeli, Catarina. "Orientalist Painting in Venice, $15^{\text {th }}$ to $17^{\text {th }}$ Centurie". Venice and the Islamic World 828 - 1797. New Haven: Yale University Press, 2007, 120-140.

Varlık, Nükhet. "Conquest, Urbanization and Plague networks in the Ottoman Empire, 1453-1600." The Ottoman World. Edited by Christine Woodhead. New York: Routledge Taylor \& Francis Group, 2012, 251-264.

Yaman, Bahattin. "Fit For the Court: Ottoman Royal Costumes and Their Tailors, from the Sixteenth to Eighteenth Century." Ars Orientalis 42 (2012): 89-101. 